\title{
Indlejret Visdom En Netværksanalyse af De Økonomiske Vismænd
}

\author{
Lasse Folke Henriksen \\ Post.doc., Department of Business and Politics, Copenhagen Business Scool (CBS) \\ Rune Møller Stahl \\ Ph.d.-studerende, Institut for Statskundskab, Københavns Universitet (KU)
}

Det kan vække undren, at diskursen om dansk økonomi er så stabil trods skiftende regeringer til højre og venstre for midten. Institutionelle og Aktør-netværksteoretiske studier af politisk økonomi undersøger forbindelser mellem vidensparadigmer, formler og konkrete personer i udformningen af økonomisk politik. Lasse Folke Henriksen og Rune Stahl Møller viser ved hjælp af et netværksanalytisk studie, at det også er centralt at forstå de økonomiske vismænds forbindelser til eliten inden for politik og erhvervsliv. Disse netværk giver et fingerpeg om, hvordan der kan opstå stærk konsensus om den rette økonomiske politik.

\section{Indledning ${ }^{1}$}

De fleste danskere vil kende formandskabet for det Økonomiske Råd under dets folkelige betegnelse, de økonomiske vismand. Rådet er i årtier gået under denne betegnelse uden at blive genstand for satire eller latterliggørelse og har i den senere tid endda selv benyttet betegnelsen, omend i anførselstegn (Whitta-Jacobsen 2012). Fem årtier efter sin oprettelse står det Økonomiske Råd som en af de længst eksisterende og mest indflydelsesrige ekspertinstitutioner i Danmark med bred anderkendelse fra både regering, fagbevægelse og erhvervslivets organisationer (Børsting 2012; Christensen 2002; Kristensen 2002; Pedersen \& Campbell, forthcoming) og en markant tilstedeværelse i den offentlige debat, især i forbindelse med publiceringen af de halvårlige rapporter (Vestergaard 2002). I verserende kontroverser om den økonomiske politik har Rådet, selv under pres, formået at fastholde legitimitet som formidlere af en særlig økonomisk faglighed (Marcussen 2002). Denne centrale placering er ikke tilfældig. Vores analyse viser at vismændene har et bredt netværk, der rækker langt ud over den akademiske verden, og sammenlignet med andre økonomiprofessorer, er de betydeligt stærkere indlejret i de bredere beslutningsnetværk i den danske politiske økonomi.

I den internationale forskningslitteratur indenfor politologi og sociologi er det efterhånden velbeskrevet, hvordan vi i det seneste årtier har set en tiltagende betydning af videnskabelig viden og evidens i de politiske beslutningsprocesser, og at den økonomiske videnskab har en særlig status i denne proces (Korpi 1996, Campbell 1998, Backhouse 2009, Fine 2009). Disse analyser har dog hovedsageligt set på det indholdsmassige udfald, og vi har ikke set nogen systematisk behandling af fagøkonomers strukturelle placering i den politiske økonomi. Det sidste er et vigtigt perspektiv, da placering i netværksteoretisk forstand udgør en afgørende mulighedsbetingelse for udøvelsen af den indholdsmæssige påvirkning af bredere samfundsmæssige beslutningsprocesser. Det netværksteoretiske perspektiv betyder at vi ikke berører aspekter som den rene forskningsmæssige indflydelse målt på akademiske citationer eller indflydelse via synlighed i medierne (se her fx Madsen 2009).

En netværksanalyse kan konceptualisere videnskabelige eksperters indlejring i bredere beslutningsmæssige netværk ved at kortlægge deres relationer til andre aktører og institutioner. På den måde undgår analysen en dualistisk forståelse af forholdet mellem politik og videnskab som to uafhængige sfærer med forskellige og uforbundne logikker. Netop denne forståelse har domineret meget af den akademiske debat om de økonomiske vismænd i form af eksempelvis spørgsmålet om, hvorvidt disse kan anses som „uafhængige eksperter“. I stedet for denne dualistiske tilgang, tillader en netværksanalytisk tilgang at se både politiske og forskningsmæssige aktører som spillere $i$ et bredere politisk-økonomisk landskab.

Artiklen undersøger med dette udgangspunkt de økonomiske vismænds personlige netværk og viser, at de har stærke forbindelser til beslutningstagende institutioner - ikke kun inden for den akademiske verden og staten, men også i erhvervslivet, fagbevægelsen og organisationslivet i øvrigt. Vismændene står således som et 
centralt punkt mellem forskningsverdenen, det politiske system og den bredere organisationsverden. Vi argumenterer på denne baggrund for, at deres centralitet i politiske beslutninger ikke kun skal forstås som et resultat af deres direkte adgang til det politiske system, men også i lyset af denne institutionelle indlejring $i$ den bredere politiske økonomis beslutningsnetværk. Vi argumenter i forlængelse heraf for, at vismændene pga. deres centralitet har mulighed for at spille en vigtig rolle i definitionen af den videnskabelige ramme for politisk-økonomiske diskussioner i den brede samfundsdebat og således i betydelig grad bidrager til at reproducere den snævre faglige konsensus, der præger den samfundsøkonomiske debat i Danmark.

Gennem en kombination af netværks-, korrespondance- og klyngeanalyse af vismændenes personlige netværk påviser vi dels deres beslutningscentralitet og dels deres divergerende institutionelle indlejring. Denne metodekombination er generelt anvendelig til at identificere variationer $i$ institutionelle konfigurationer, som eksperter indgår $\mathrm{i}, \operatorname{dog}$ uden at give indblik i hvordan beslutningsprocesser påvirkes indholdsmæssigt, som må eftervises på anden vis.

Artiklen er struktureret sådan, at vi først giver et kort rids over det økonomiske råds historie og forskningslitteraturen på området. Dernæst placerer vi vores analyse i forhold til videnskabssociologisk og institutionel teori. Vi præsenterer derpå data, som analyseres i to dele: Først gives en beskrivelse af netværksstatistikken for vismændene, og derefter identificerer vi forskellige vismænds netværksroller ud fra sammensætningen af deres forbindelser. Slutteligt opridser vi artiklens hovedkonklusioner.

\section{Historisk kontekst}

Det Økonomiske Råd blev oprettet af den danske regering i 1962 for at fungere som et uafhængigt rådgivende organ, der skulle analysere den økonomiske udvikling og rapportere til Regering og Folketing. Etableringen af rådet var især fremført af den radikale økonomiminister Kjeld Philip med støtte fra regeringspartnerne i socialdemokratiet (Mikkelsen 1987, 188).

Rådet ledes af et formandskab af fire meriterede økonomiske forskere, ${ }^{2}$ de økonomiske vismænd, som leder et fagøkonomisk sekretariat på ca. 30 medarbejdere. Selve det Økonomiske Råd består af repræsentanter for erhvervslivet og fagbevægelsen. Desuden er Nationalbanken, forskellige ministerier og forbrugerorganisationer repræsenteret, samt en række udpegede eksperter.

I Lov om Det Økonomiske Råd formuleres de to hovedopgaver som ,at følge landets økonomiske udvikling og belyse de langsigtede udviklingsperspektiver samt at bidrage til at samordne de forskellige økonomiske interes- ser.“" (Indenrigsministeriet 2007 [1962]). Intentionen med oprettelsen var dermed todelt. På den ene side skulle Rådets formandskab give en 'uafhængig' vurdering af den økonomiske situation. På den anden side var Rådet også tænkt som en del af det danske korporative system, hvor det skulle være et forum for koordineringen mellem staten og arbejdsmarkedets parter, oprindeligt med særligt henblik på koordinering af lønstigninger gennem indkomstpolitik. Den sidste rolle, som koordinator mellem arbejdsgivere og fagbevægelsen, er dog aldrig kommet til at spille den store rolle i praksis, idet arbejdsmarkedets parter i høj grad modsatte sig, at Rådet kom til at fungere som arbitrator med autoritet til at sætte den årlige lønstigningsrate (Due \& Madsen 2012). I stedet er det rådets anden rolle, som fagøkonomisk analyseinstitution, som har været den dominerende. I løbet af Rådets historie har det vist sig at være formandsskabet i samspil med et stærkt bemandet fagøkonomisk sekretariat, der har tegnet institutionen gennem publikationen af de halvårlige rapporter, som vurderer den økonomiske situation i Danmark. Selvom formandskabet formelt er udpeget af Økonomiministeriet, har det i praksis fået en vid grad af autonomi. Tidligere overvismand Niels Kærgaard beskriver, hvordan Økonomiministeren siden slutningen af 1960 ,har fulgt formandskabets egne indstillinger om sammensætningen, således at rådet reelt er selvsupplerende" (Kærgård 1996, 116).

\section{Eksperter: mellem institutioner og netværk}

I den dansksprogede forskningslitteratur er Rådet behandlet, særligt inden for fagøkonomien men også i nogen grad i den politologiske litteratur. Hovedvægten har været på de konkrete økonomiske anbefalinger, som forskellige formandskaber er kommet med. Blandt de vægtigste i de senere årtier her er debatten om de økonomiske konsekvenser ved en dansk indtrædelse i Euroen (Marcussen 2002 ; Ølgaard 2002) og vurderingen af finanspolitikken under 00'ernes boligboble (Sørensen 2013; Sørensen $\&$ Rosholm 2009). I det omfang institutionens rolle har været behandlet, er det især tidligere eller nuværende vismænd, som har reflekteret over rådets rolle og deres egen praksis. Fokus i denne litteratur har i høj grad været på Rådets forhold til det politiske system, og hvordan Rådet har opretholdt sin faglige uafhængighed uden at miste politisk relevans og gennemslagskraft (Kærgård 1996; Sørensen \& Rosholm 2009; Ølgaard 1977 2002). I Rådets 50-års jubilæumsskrift opsummerer Overvismand Jørgen Whitta-Jakobsen, hvordan „uafhængighed er et helt afgørende nøgleord“ for Rådet, og at ,institutionens eksistensberettigelse bygger på faglig styrke og høj troværdighed" (Whitta-Jacobsen 2012, 9). Denne analyse støttes af tidligere overvismænd Niels Kærgård (1996) og 
Torben M. Andersen, hvor sidstnævnte i 2002 konstaterer at „der ikke er nogen partipolitisk bias i rapporterne fra det økonomiske råd“" (Andersen 2002).

Mens det er forståeligt, at praktikere som bevæger sig på grænsefladen mellem det politiske og videnskabelige liv reflekterer over spørgsmål om partipolitisk uafhængighed, mener vi imidlertid, at et fokus på spørgsmålet om den uafhængige ekspertrolle kan skygge for en bredere forstålse af rådets reelle forbundethed til bredere lag af beslutningstagere. Det økonomiske råd er i dag et af de stærkeste rådgivende organer i Danmark. Grunden til dette, vil vi argumentere, er i høj grad, at institutionen netop ikke er uafhængig: men snarere tværtimod dens stærke afhængighed, eller indlejring, i de beslutningstagende netværk i og omkring det politiske system. Disse netværk udgøres ikke kun af valgte politikere, men lige så vigtigt af centrale beslutningstagere i øvrige samfundsinstitutioner. Kombinationen af at være indlejret i disse netværk men uden formelt at være en del af det politiskadministrative hierarki, har bidraget til at institutionen er kommet til at stå som en central formidler af fagøkonomisk ekspertise til såvel det politiske system som beslutningstagere og befolkningen i øvrigt. Rådets stabilitet som indflydelsesrig institution samt vismændenes brede netværk sammenlignet med deres universitetskollegaer vidner om den faglige og samfundsmæssige status.

Den politiske betydning af økonomiske ideer og akademisk økonomi har vundet indpas i den videnskabssociologiske såvel som institutionalistiske litteratur i de to seneste årtier. I Halls vigtige artikel fra (1993) låner han Kuhns begreb om paradigmeskifte til at forstå, hvordan forskydninger i teoretiske grundforståelser af økonomien fører til skift i den førte økonomiske politik på forskellige niveauer. Siden da er talrige studier af økonomiske ideers indtog i det politiske liv kommet til, oftest med særligt fokus på betydningen af udbredelsen af neoklassisk teori og nyliberale ideer i centrale samfundsinstitutioner såvel nationalt (Hay 2001; Blyth 2002; Fourcade 2009; Lindvall 2009; Schmidt 2011) som internationalt (Marcussen 2000; Chwieroth 2009).

Et nyere eksempel på denne litteratur er John Campbell og Ove Kaj Pedersen (Pedersen \& Campbell 2014), som i deres kommende værk om økonomiske vidensregimer beskriver, hvordan Danmark i højere grad end øvrige lande, ${ }^{3}$ er præget af konsensus omkring væsentlige samfundsøkonomiske spørgsmål på tværs af politiske og institutionelle skel, mellem fx fagbevægelse og erhvervsliv. Pedersen beskriver desuden denne konsensus som stærkt forbundet til konstruktionen af det, han kalder den 'samfundsøkonomiske forestilling'; en fælles forståelse af den nationale økonomiske politik, der præger den fag$ø$ konomiske mainstream på universiteterne, økonomisk tænkning i centraladministrationen samt størstedelen af Folketinget (Pedersen 2011, 126). Pedersens begreb minder om Peter Halls 'policy-paradigme', som han definerer som et sammenhængende sæt af kognitivt indlejrede, inter-subjektivt afstemte antagelser og teorier om, hvordan en policy-genstand ( $\mathrm{fx}$ samfundsøkonomien) opfører sig (Hall 1993, 280). For at beskrive hvordan et sådant paradigme, eller samfundsøkonomisk forestilling, konstrueres, bør man imidlertid ikke blot se på, hvordan de indlejres i institutioner på makroniveau, men også afdække hvilke centrale aktører, der producerer og reproducerer paradigmet samt udpege de konkrete netverk, som de opererer gennem.

Indenfor videnskabssociologien er et sådan perspektiv på økonomisk ekspertise bl.a. blevet fremført af Michel Callon (1998) og Donald MacKenzie (2006), der lægger vægt på økonomers betydning i opbygningen af markeder og andre økonomiske institutioner, herunder specifikt hvordan ikke kun teorier, men også tekniske værktøjer, såsom modeller og regnemetoder, kan blive konstitutive i det konkrete netværksarbejde, som den fagøkonomiske verden defineres af. Særligt fokus har der her været på, hvordan eksperter bliver centrale, når de er i stand til at forbinde netværk i den akademiske vidensproduktion med netværk hvor denne viden kan få en fremtrædende rolle i praksis (Callon 1998, 1986 MacKenzie 2006, Chwieroth 2009)4.

Udover ekspertnetværk er betydningen af netværk i det private erhvervsliv også blevet fremført inden for den amerikanske netværksanalytiske tradition. Fx har John Scott vist, hvordan bestyrelsesarbejde spiller en central rolle i koordination og vidensspredning inden for industrier og sågar hele økonomier (Scott 1991), mens Michael Useem beskriver, hvordan repræsentantskaber i virksomhedsbestyrelser ikke blot er med til at sprede information mellem USA's største virksomheder, men også at skabe konsensus om en særlig verdensforståelse (Useem 1984).

Tilsammen har disse litteraturer skabt opmærksomhed omkring den fagøkonomiske profession som en samfundsgruppe, hvis strategiske indflydelse fortjener empirisk opmærksomhed. I denne artikel trækker vi på indsigter fra både den institutionalistiske og netværksanalytiske tradition ved at argumentere for, at en specifik gruppe af fagøkonomer, nemlig vismændene, i særlig grad binder den fagøkonomiske vidensproduktion sammen med centrale beslutningsnetværk i den samfundsøkonomiske virkelighed via deres brede repræsentation i sidstnævnte. Gennem en kortlægning af vismændenes personlige netværk på tværs af institutioner inden for videnskab, politik, medier, erhvervsliv og fagbevægelse, udpeger vi den netværksstruktur, som giver vismændene mulighed for overhovedet at øve indflydelse på centrale 
samfundsøkonomiske beslutninger. Artiklen beskæftiger sig således ikke direkte med de kampe, hvor det diskursive eller ideologiske indhold i den 'samfundsøkonomiske forestilling' bestemmes (Pedersen 2011), men søger snarere at pege på de netværksstrukturer, som muliggør den relative indholdsmæssige enighed om samfundsøkonomiske spørgsmål, der hersker på tværs af institutioner.

Vi trækker således på den netværksteoretiske forståelse af sociale aktører som konstitueret i forbindelser til andre aktører. Det væsentlige er dermed ikke blot aktørernes egenskaber og institutionelle tilknytning, men også deres rolle og placering i netværket. Netværksteori udpeger ydermere nye aspekter af social ulighed og magtfordeling, som baserer sig på aktørers forholdsmæssige placering i et netværk snarere end iboende karakteristika (Wellmann 1988, Emirbayer 1997) og sigter typisk mod at karakterisere netværksstrukturer og aktørpositioner med henblik på at forklare konsekvenserne af aktørernes 'indlejring' i disse strukturer og positioner for deres handlemåde (Granovetter 1985, Borgatti and Halgin 2011). Konventionelt defineres netværk som et sæt af aktører, eller 'noder', og et tilhørende sæt af relationer, eller forbindelser, som binder aktørerne sammen. Relationerne i netværk sammenbindes af 'delte' aktører og udgør således 'stier' eller 'rør', som indirekte forbinder aktører, der ellers ikke ville være forbundne (Borgatti \& Halgin 2011). I det følgende afsnit præsenterer vi en analyse af, hvordan vismændene forbinder centrale samfundsinstitutioner gennem deres indlejring i netværk og peger på forskellige roller alt efter hvilke specifikke institutioner, de binder sammen i deres netværk.

\section{Vismændenes netværk}

Vores datasæt består af samtlige poster i væsentlige offentlige og private bestyrelser, kommissioner, råd og nævn, med deltagelse af nuværende og tidligere økonomiske vismænd i 2012. Disse poster kan stamme fra placeringer i forbindelse med posten som vismand, eller være udpegelser, som er sket uafhængigt af posten. Data er trukket fra Christoph Ellersgaard og Anton Larsens (2012) database „The Danish Elite Network" som består af ledende positioner i 5830 organisationer i Danmark. ${ }^{5}$ Dermed har vi vismændenes samlede netværksforbindelser via officielle positioner samt disse forbindelsers institutionelle tilknytning. Ud af de i alt 33 økonomer, der har siddet som økonomiske vismænd siden 1962, optræder 20 i vores datasæt. $^{6}$

Personerne i datasættet er kategoriseret i forhold til hvilke centrale samfundsinstitutioner, de havde deres primære ansættelsesforhold til i 2012. Som beskrevet ovenfor blev vismandsinstitutionen etableret som en del af den korporative forhandlingsstruktur, hvor erhvervsliv, fagbevægelse og staten sammen skulle koordinere centrale samfundsøkonomiske spørgsmål. Ud over disse tre samfundsinstitutioner, har vi også inkluderet forskningsverdenen (universitet og andre forskningsinstitutioner), medier og kultur samt andre interesseorganisationer (organisationer der ikke er direkte forbundet med arbejdsgiver eller lønmodtagerinteresser, fx miljøorganisationer).

Hvis vi sammenligner vismændene med resten af de danske økonomiprofessorer ${ }^{8}$, er de markant stærkere forbundet til disse institutioner. Tidligere og nuværende vismænd udgør $9 \%$ af den samlede population af økonomiprofessorer, men alligevel sidder de på $49 \%$ af de 77 officielle pladser i bestyrelser, kommissioner og råd, som indtages af den fagøkonomiske professorstand i 2013. Gruppen „øvrige professorer" har i gennemsnit 0,44 positioner pr. person, mens gruppen af vismænd ligger næsten ti gange så højt med 4,2 positioner pr. person.

Med ovennævnte data konstruerer vi en netværksmatrice over samtlige forbindelser, som de nuværende og tidligere vismænd har via deres positioner. Netværket, der analyseres i denne artikel, er aggregeret fra vismændenes personlige netværk, hvorved de naturligt bliver centrale aktører. Vi kan altså ikke direkte drage konklusioner om vismændenes placering i den samlede danske magtelite (se Ellersgaard \& Larsen 2012). Det samlede netværk, som ligger til grund for analysen, består af 398 personer, hvoraf 20 er vismænd som tilsammen har 59 af de i alt 538 positioner, som netværket er konstrueret ud fra, og 590 forbindelser samlet. Tabel 1 viser fordelingen af vismændenes forbindelser på institutionsniveau og det samlede antal forbindelser på tværs af institutioner.

Som det fremgår i tabellen, er det de 214 forbindelser til erhvervslivet, der fylder mest i vismændenes personlige netværk. Forskningsverden og den offentlige sektor scorer hhv. 158 og 100 forbindelser, mens fagbevægelse og de øvrige sektorer ligger markant lavere. Noget af denne skævvridning kan skyldes, at datasættet indeholder mange kommissioner og erhvervsbestyrelser.

Selvom vismændene er naturligt centrale i netværket, er personer fra de øvrige samfundsinstitutioner også forbundet uden om dem. Som man kan se i tabel 1, er trekanten mellem erhvervsliv, forskning og offentlige personer stærkest forbundet. Især er der mange forbindelser mellem den akademiske verden og erhvervslivet.

I figur 1 ses en grafisk repræsentation af netværket, hvor dog kun personer med to eller flere forbindelser til de økonomiske vismænd optræder. Således optræder Karsten Laursen, Niels Blomgren-Hansen, Arne Larsen og Bent Rold Andersen ikke i denne repræsentation, da de kun optræder i én bestyrelse i datasættet. Nodernes størrelse er skaleret efter antallet af personernes forbindelser (se nedenfor). 
Tabel 1: Forbindelser opgjort på samfundsinstitutioner

\begin{tabular}{lcccccc}
\hline & Vismænd & Offentlig & Erhvervsliv & Forskning & Fagbevægelse & Kultur-medier \\
\hline Offentlig & 100 & & & & & \\
Erhvervsliv & 214 & 308 & & & & \\
Forskning & 158 & 161 & 398 & & & \\
\hline Fagbevægelse & 58 & 70 & 215 & 53 & 5 & 19 \\
\hline Kultur-medier & 32 & 54 & 132 & 85 & 15 \\
\hline Andre organisationer & 28 & 34 & 78 & 44 & \\
\hline
\end{tabular}

Kilde: (Ellersgaard \& Larsen 2012) samt egne beregninger.

Som det fremgår af grafen, udgør netværket én samlet komponent, hvilket betyder, at alle grafens 16 vismænd er forbundet. Det samlede netværk bindes primært sammen af en eller nogle få 'centralt' placerede vismænd, som Nina Smith, Michael Svarer og Torben M. Andersen. Desuden er der er en række centrale personer i netværket, som ikke er eller har været vismænd. Således er LO-formand $\mathrm{Ha}-$ rald Børsting, departementschef David Helleman og DAdirektør Jørn Neergard mere centralt placeret i netværket end flertallet af vismændene, selvom kun de positioner, som forbinder dem med vismænd, er taget med i denne analyse.

Indtil videre har vi omtalt netværkscentralitet i generelle vendinger, men faktisk er der udviklet en række kvantitative centralitetsmål, der er anerkendte indikatorer på aktørers magt, indflydelse og prestige (Bonacich 1987, Borgatti 2005). Der findes 4 accepterede centra- litetsmål inden for litteraturen: Det mest simple er degree-centralitet, som måler en aktørs direkte forbindelser (Freeman 1979 219-220). Når formålet er at måle adgang til og mulighed for at sprede viden, er degree en robust indikator (jf. Borgatti 2005), hvorfor vi bruger denne i indeværende analyse samt i den grafiske repræsentation. Dog tager degree kun højde for lokal centralisering og hverken højde for graden af aktørers forbundethed i andet led (graden af forbindelsernes forbindelse), aktørers rækkevidde i netværket som helhed, eller hvor ofte de fungerer som såkaldte brokers. ${ }^{9}$ Desværre egner det foreliggende datasæt sig ikke til avancerede centralitetsanalyser, da det udelukkende består af vismændenes personlige netværk og kun andre personer i den udstrækning at disse også er forbundet til vismænd. Degree-centraliteten er dermed det eneste mål, som ikke påvirkes af denne databegrænsning.

Figur 1

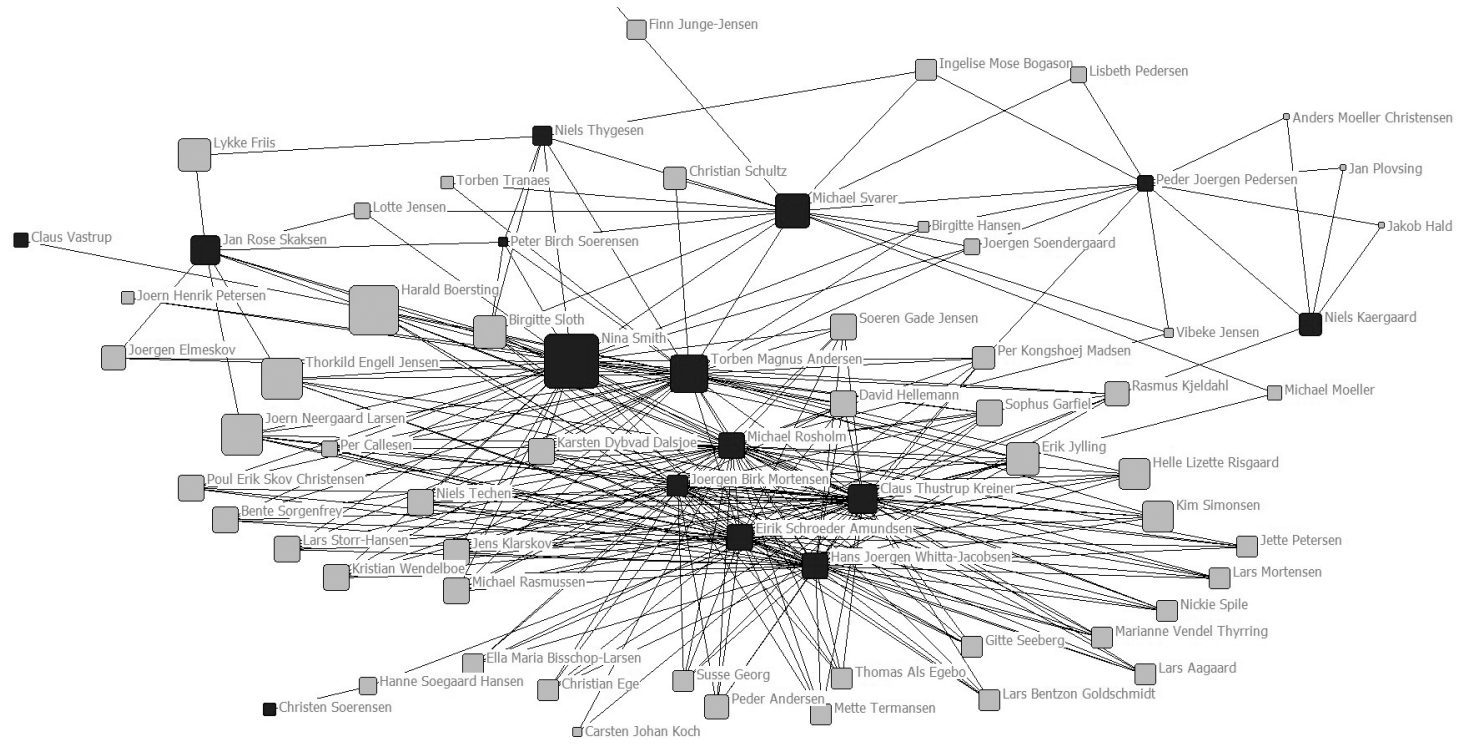


Tabel 2: Centralitet

\begin{tabular}{lllllllll}
\hline & Periode & $\begin{array}{l}\text { Samlet } \\
\text { centralitet }\end{array}$ & Offentlig & Erhverv & Forskning & Fagbevægelse & Kultur/-medier & Andre org. \\
\hline N Smith & $1995-98$ & 91 & 14 & 34 & 30 & 8 & 3 & 2 \\
\hline TM Andersen & $1993-96$ & 62 & 9 & 17 & 21 & 14 & 0 & 1 \\
& $2001-3$ & & & & & & & \\
M Svarer & $2012-$ & 56 & 2 & 11 & 38 & 0 & 5 & 0 \\
CT Kreiner & $2012-$ & 48 & 7 & 14 & 15 & 7 & 1 & 4 \\
JR Skaksen & $2003-8$ & 45 & 12 & 18 & 13 & 2 & 0 & 0 \\
\hline M Rosholm & $2006-12$ & 42 & 8 & 11 & 11 & 7 & 1 & 4 \\
\hline HJ Whitta-Jacobsen & $2009-$ & 42 & 7 & 11 & 12 & 7 & 1 & 4 \\
\hline ES Amundsen & $2007-$ & 40 & 7 & 10 & 11 & 7 & 1 & 4 \\
\hline N Kærgaard & $1992-2001$ & 36 & 4 & 9 & 20 & 0 & 1 & 2 \\
\hline E Hoffmeyer & $1962-65$ & 34 & 4 & 13 & 5 & 0 & 12 & 0 \\
\hline
\end{tabular}

Kilde: (Ellersgaard \& Larsen 2012) samt egne beregninger.

Den gennemsnitlige degree-centralitet blandt vismændene ligger på 32,7 og varierer fra 3 til 91. I Tabel 2 ses de 10 mest centrale vismænd, som alle ligger over den gennemsnitlige centralitet. Tabellen viser også fordelingen af vismændenes forbindelser på samfundsinstitutioner. Her ser vi, at stort set alle vismænd har flest forbindelser til erhvervsliv og forskningsverdenen. Samtidigt er der dog en tydelig individuel variation i den måde, som enkelte vismænds relationer fordeler sig på. Fx er Nina Smith i forhold til gennemsnittet 'overforbundet' til det offentlige, mens Torben M. Andersen tilsvarende er karakteriseret ved hans mange forbindelser inden for fagbevægelsen. $\mathrm{Vi}$ skal dog ikke give en detaljeret beskrivelse af de enkelte vismænds fordeling af forbindelser her, men i stedet lade fordelingen udgøre datagrundlaget for vores videre analyse af variationen i vismændenes institutionelle indlejring i den politiske økonomi.

\section{Vismandsklynger}

I denne del søger vi at gruppere vismændene ved hjælp af principiel komponent analyse (PKA) og klyngeanalyse. Analysen foretages på fordelingen af vismændenes institutionelle forbindelser (jf. Tabel 2). PKA bruges til at komprimere og klassificere data. Formålet med PKA er at reducere antallet af variable i et datasæt ved at finde nye variable, der indfanger mest mulig variation fra de originale variable i datasættet. Disse nye variable kaldes også principielle komponenter. Fordelen ved PKA er, at de principielle komponenter, eller dimensioner, som vi per konvention skal kalde dem, er udtrykt i geometriske rum med tilhørende distancer mellem de originale variable. Dimensionerne kan således forstås som en 'dominerende modsætning' mellem variable, som beskrives i et rumligt kontinuum. Hvis en vismand 'scorer' højt på én variabel
( $f x$ antal forbindelser til offentlige institutioner), er denne høje score ofte ledsaget af en tilsvarende lav score på en anden variabel. Vismænd, hvis variabeludfald ligner hinanden, vil således have en kort afstand til hinanden. Når vi med PKA har beregnet geometriske afstande mellem vismændene, kan vi således foretage en klyngeanalyse og placere dem i klynger, eller grupper, som udgøres af vismænd med en relativ geometrisk nærhed. I denne analyse har vi ekskluderet de nuværende vismænd, da deres placering næsten udelukkende er bestemt af deres medlemskab af det økonomiske råd, og de derfor har næsten identiske forbindelser.

Som nævnt er en af de klare fordele ved PKA, at den fordrer en intuitiv geometrisk forståelse af, hvordan variables udfaldsrum grupperer sig i et rumligt kontinuum. Er der fx en gruppe i vores datasæt, som udmærker sig ved at være stærkt forbundet inden for stat og erhvervsliv men i udstrakt mindre grad inden for forskning og fagbevægelse? Eller en gruppe der er karakteriseret ved en ligelig fordeling af forbindelse på tværs af sektorer? PKA er velegnet til at besvare sådanne spørgsmål, fordi teknikken går ud på at finde 'skjulte' konfigurationer i data baseret på samvarians mellem en række variable.

I Tabel 3 præsenterer vi dimensionerne, som altså udgøres af de dominerende variabelmodsætninger. Typisk udvælger man sine dimensioner på baggrund af tre hensyn: 1) De valgte dimensioner skal gerne mindst forklare $80 \%$ af den samlede variation; 2 ) de valgte dimensioners forklaringskraft skal gerne være større end gennemsnittet af det samlede antal af dimensioner; men dimensionerne skal også 3) bidrage med et betydeligt spring i analysens samlede forklaringskraft (Ferré 1995). Ved anvendelse af disse tre principper når vi frem til fire dimensioner, som samlet forklarer ca. $92 \%$ af variansen, som er vist i tabel 
Tabel 3: Dimensioner

\begin{tabular}{lcccccccc}
\hline & Dim.1 & ctr & Dim.2 & ctr & Dim.3 & ctr & Dim.4 & ctr \\
\hline Stat & .240 & 2.873 & .028 & .063 & -.856 & $\mathbf{6 1 . 2 9}$ & .310 & 14.98 \\
Erhvervsliv & $\mathbf{- . 9 1 6}$ & $\mathbf{4 1 . 7 4}$ & .291 & 6.644 & .177 & 2.62 & -.084 & 0.69 \\
Forskning & $\mathbf{. 7 7 6}$ & $\mathbf{2 9 . 9 9}$ & -.328 & 8.458 & .047 & .185 & $-\mathbf{. 5 1 3}$ & $\mathbf{2 5 . 9 4}$ \\
Faghevægelse & .406 & 8.211 & $\mathbf{. 7 9 1}$ & $\mathbf{4 9 . 1 7}$ & .011 & .011 & .227 & 5.09 \\
Kultur/Medier & .036 & .065 & $\mathbf{- . 5 6 7}$ & $\mathbf{2 5 . 2 6}$ & .379 & 12.03 & $\mathbf{. 7 1 1}$ & $\mathbf{4 9 . 8 4}$ \\
Andre organisationer & .587 & 17.11 & .364 & 10.39 & $\mathbf{. 5 3 4}$ & $\mathbf{2 3 . 8 5}$ & .188 & 3.47 \\
\hline
\end{tabular}

Killde: (Ellersgaard \& Larsen 2012) samt egne beregninger.

1. Ved at reducere antallet af variable fra 6 til 4 mister vi altså 'kun' $8 \%$ af den samlede information i data.

Per konvention rapportereres den dimension med størst forklaringskraft som den første dimension. I dette tilfælde indfanger den ca. $34 \%$ varians i data, mens de tre andre dimensioner indfanger hhv. $21 \%, 19 \%$ og $17 \%$. For nemheds skyld kalder vi den første dimension primardimensionen mens de andre dimensioner er sekundardimensioner.

I Tabel 3 ses de fire dimensioner med deres fire dominerende variabel-modsætninger. Den første kolonne indeholder en variabels rumlige koordinat (Dim. 1), som plottes grafisk (se Figur 2) for at vise de grafiske afstande mellem variabler. En variabel med et negativt koordinat- punkt adskiller sig i udfaldsrummet betydeligt fra en variabel med et positivt koordinatpunkt. Herefter vises det procentvise bidrag til dimensionen i anden kolonne. Som det fremgår, bidrager variablene erhvervsliv og forskning mest i primærdimensionen, men der er stor afstand mellem deres koordinatpunkter, hvilket betyder, at personer der har relativt mange forbindelser til forskningen har tilsvarende relativt færre forbindelser til erhvervslivet. I sekundærdimensionen gør dette sig tilsvarende gældende for kultur/medier over for fagbevægelse, 3) stat vs. andre interesseorganisationer og 4) forskning vs. kultur/medier for sekundærdimensionerne. De første 3 dimensioner indeholder således alle 6 variabler i de styrende variabel-par. Dette fortæller os, at variansen i alle 6 samfundsinstitu-

Figur 2

Plot over dimension 1 og 2

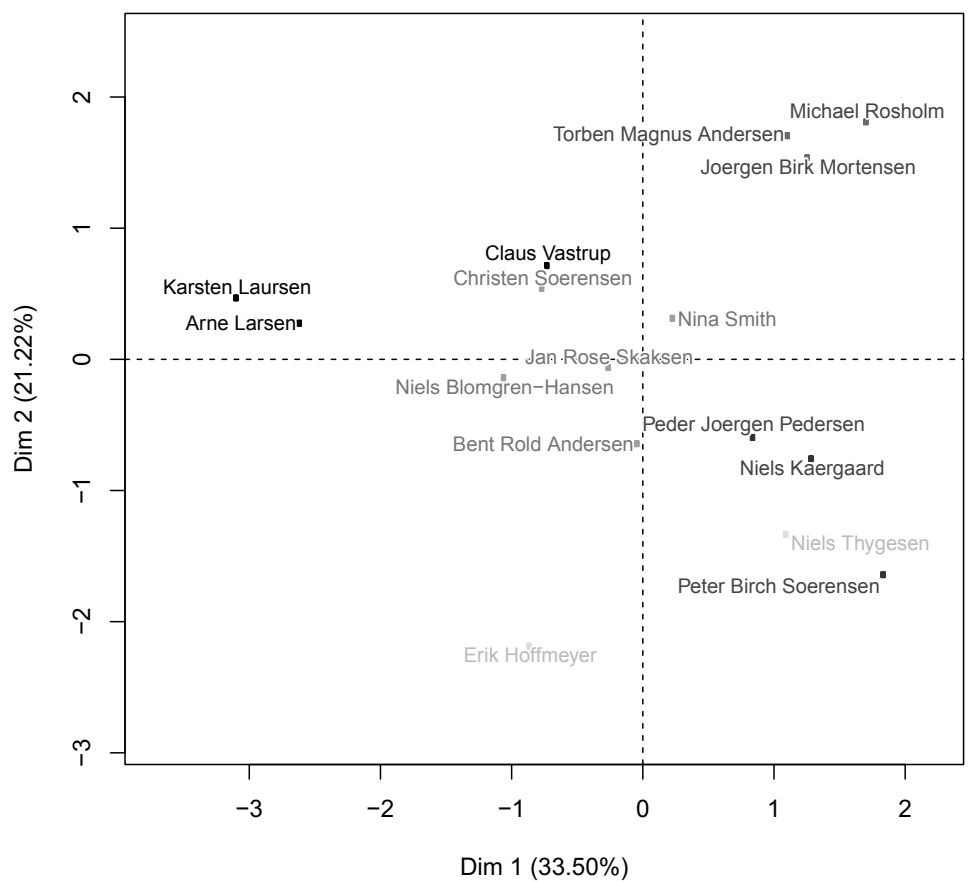


tioner bidrager til at forklare variansen i datasættet som helhed. Ydermere fortæller det os, at vismænd, der har relativt mange erhvervslivsforbindelser, ofte har relativt færre forbindelser inden for forskning. Vismænd, der er stærkt forbundet til kultur/medier, har til gengæld relativt færre forbindelser inden for fagbevægelsen ligesom forbindelser inden for staten synes at hænge sammen med et fravær af forbindelser til andre organisationer. På sidste dimension er det igen forskning og kultur/medier, der driver forskellene.

Med ovenstående dimensioner kortlagt kan vi plotte vismændene grafisk på baggrund af deres geometriske afstande. Udfordringen rent grafisk består i, at vores analyse identificerer 4 dimensioner, hvilket umuliggør ét samlet plot. Vi baserer således vores analyse på fire dimensioner, hvor primærdimensionen udgør x-aksen, mens y-aksen varierer i sekundærdimensionen. Af pladshensyn præsenterer vi her dog kun de første to dimensioner grafisk (figur 2). Vi er nu interesserede i at gruppere vismændene på baggrund af deres 4-dimensionelle koordinater. Vi gør dette med en konventionel hierarkisk klyngeanalyse, som knytter de vismænd sammen, hvis afstand er mindst. Kunsten her er at vælge det rette antal klynger. Her følger vi samme princip som for udvælgelse af dimensioner. Vi knytter en særlig vægt til det såkaldte Scree Plot, som viser forholdet mellem antallet af klynger og hvor stor en del af den samlede varians i de geometriske distancer disse indfanger. Ud fra disse principper er fem klynger det optimale antal, da der fra 4 til 5 grupper er sket betydeligt spring i, hvor godt de gennemsnitlige koordinater i klyngerne passer med de egentlige individuelle koordinater, mens dette spring altså er betydeligt mindre, når vi forøger antallet af klynger til 6 og opefter.

De fem klynger kan adskilles efter fordelingen af forbindelser. Det skal til at starte med understreges, at alle 5 klynger er relativt stærkt forbundet til erhvervslivet, hvilket også er et resultat af, at erhvervsbestyrelser dominerer datasættet. Det er dog alligevel værd at bemærke, at ingen af klyngerne er mærkbart uforbundet til erhvervslivet. Derudover er der en række systematiske forskelle, der karakteriserer de fem klynger. Fordelingen for de enkelte klynger kan ses i tabel 4.

Den forste klynge består af vismænd, som er betydeligt mest forbundet til erhvervslivet, men til gengæld har væsentligt færre forbindelser i forskningsverdenen og slet ingen forbindelser i staten. Den første klynge har ligeledes et væsentligt mindre samlet antal forbindelser end den gennemsnitlige vismand, ligesom det er over 20 år siden, at dens medlemmer har bestredet rollen som vismand. En nærliggende forklaring på denne gruppes indlejringsmønster er således deres alder og arbejdsmarkedsstatus, hvor erhvervsforbindelser altså synes 'nemmere' at vedligeholde end statslige og forskningsmæssige, hvor det formentlig kræver officiel beskæftigelse at bestride en position.

Den anden klynge består af vismænd med en særlig tilknytning til fagbevægelsen på bekostning af at være nærmest uforbundet i kultur/medier. Denne gruppe skiller sig også ud ved at have en høj degree-centralitet. Med sin samtidige stærke tilknytning til både fagbevægelse, erhvervsliv og den offentlige sektor peger denne gruppes forbindelser på en klassisk korporativ rolle, hvor fagøkonomer medierer mellem staten og arbejdsmarkedet parter og således potentielt bidrager til dannelsen af en konsensus-baseret samfundsøkonomisk forestilling blandt de besluttende lag. Medlemmer af denne gruppe har alle været vismænd for nyligt, og flere spiller en fremtrædende rolle i samfundsdebatten, som Torben M. Andersen, der bl.a. er tidligere formand for velfærdskommissionen. Denne observation støtter op om forståelsen af vismandsinstitutionen som en del af en korporativ struktur, idet indlejringsmønstret for umiddelbart aftrædende vismænd viser en bred integration, der sammenbinder stat, fagbevægelse og erhvervsliv

Den tredje og største klynge er karakteriseret ved dens medlemmers stærke statslige forbindelser kombineret med markant færre forbindelser til 'andre organisationer'. Antallet af forbindelser inden for denne klynge varierer desuden meget - med Nina Smith og Jan Rose Skaksen som de mest forbundne (hhv. 91 og 45) som står i stærk kontrast til Bent Rold Andersen og Niels BlomgrenHansen med kun få forbindelser (hhv. 3 og 6). Selvom de altså deler den relative fordeling af forbindelser på institutioner, undrer det ikke, at Smith og Skaksen træder frem som centrale medlemmer: de er begge kendt som offentlige eksperter og fra deres rolle i offentlige kommissionsarbejder.

Den fjerde klynge er særligt stærk forbundet til forskningsverdenen og er igen næsten uden forbindelser til kultur/medier eller fagbevægelse. Dette kunne tyde på at medlemmerne af denne klynge primært spiller en rolle $\mathrm{i}$ forskningsverden, med relativt mindre vægt på poster i ikke-akademiske fora. Klyngen består bl.a. af Niels Kærgård, som bl.a. er kendt for diskussion af fagøkonomiens rolle og historie i Danmark, og Peter Birch Sørensen, som har en mere international profil. Det kan undre, at Sørensen ikke har flere forbindelser til offentlige institutioner, eftersom han har været medlem af skattekommissionen og fungerede som formand for Produktivitetskommissionen. Alligevel er hans forbindelses-portefølje anno 2012 altså præget af forskningsverdenen, hvilket kan hænge sammen med, at produktivitetskommissionen er domineret af forskere. 
Den femte og mindste klynge er som den eneste karakteriseret ved at være indlejret meget stærkt i kultur/ medier, mens de slet ingen forbindelser har i fagbevægelsen og kun er lidt forbundet til forskning. Denne klynge består bl.a. af Erik Hoffmeyer, som er tidligere Nationalbankdirektør.

\section{Konklusion}

I denne artikel har vi kombineret en institutionel- og netværksanalytisk tilgang til at forstå eksperters politiske og samfundsmæssige rolle. På den ene side argumenterer vi for, at forstå eksperters politiske rolle ud fra de netværk, de er indlejrede i. Men vi undersøger ligeledes, hvordan disse netværk forbinder centrale samfundsinstitutioner og således udgør den relationelle infrastruktur, gennem hvilken en dominerende 'samfundsøkonomisk forestilling' dannes og spredes og herigennem kan påvirke politiske beslutningsprocesser. Vi har anvendt vismændenes personlige netværk til at forstå deres institutionelle indlejring i den politiske økonomi og præsenteret en ny metode til at udpege dominerende indlejringsmønstre, hvor vi trækker på netværks-, korrespondance- og klyngeanalytiske redskaber. Vi har ligeledes argumenteret for, at vismændene spiller en særlig central rolle som fagøkonomiske eksperter, idet de er langt tættere knyttet til det politiske liv og samfundsøkonomiens besluttende lag end andre akademiske økonomer.

I analysen har vi således kombineret det institutionelle og personlige niveaus forbundne karakter med et blik for de centrale aktører, som udgør forbindelserne mellem disse institutioner. Vi har desuden peget på, at fagøkonomers rolle i konstruktionen af den 'samfunds$ø$ konomiske forestilling' oftest er blevet analyseret indholdsmæssigt med institutionelle tilgange, mens deres strukturelle placering på samfundsniveau har været empirisk underbelyst, selvom denne placering udgør en afgørende mulighedsbetingelse for udøvelsen af en indholdsmæssig påvirkning af politiske beslutningsprocesser.

I denne forstand bidrager artiklen empirisk med en konkret kortlægning af vismændenes institutionelle indlejring men også med en tilgang og metode til at studere andre ekspertinstitutioners strukturelle placering og adgang til at påvirke politiske beslutningsprocesser. Ved at benytte en netværksanalytisk tilgang kan videnskabelige eksperters forhold til det politiske system således konceptualiseres på en måde, der ikke reducerer forholdet til en dualistisk modstilling mellem forskellige logikker, men i stedet ser både politiske og forskningsmæssige aktører som spillere i et bredere politisk-økonomisk landskab.

Først og fremmest har analysen demonstreret, at vismændene, i forhold til fagøkonomer på sammenligneligt karriereniveau, er markant stærkere forbundet til beslutningstagere uden for universitetet. Dette tyder på, at vismandsinstitutionen ikke kun øver direkte indflydelse gennem rådsmøder og publiceringen af de halvårlige rapporter, men også giver tidligere vismænd en særlig status og adgang til de vigtige samfundsøkonomiske beslutninger, som træffes på hverdagsbasis i policy-processer og bestyrelsesarbejde inden for erhvervslivet mv.

Endvidere finder vi, at vismændene i betydelig grad agerer forbindelsesled mellem forskellige institutioner på samfundsniveau. Igen opstår denne forbindelse ikke kun gennem de formelle rådsmøder, men ligeledes gennem de netværk som tidligere vismænd får adgang til qua deres status som tidligere vismænd. I artiklen finder vi dog en betydelig variation i vismændenes netværksplacering, hvor nogle få vismænd er centralt placerede med mange forbindelser til forskellige samfundsinstitutioner, mens en større gruppe har færre forbindelser koncentreret omkring et mere snævert sæt af institutioner. Vi identificerer

Tabel 4: Klynger af vismænd

\begin{tabular}{|c|c|c|c|c|c|c|c|c|c|}
\hline Klynge & $\begin{array}{l}\text { Medlem- } \\
\text { mer }\end{array}$ & $\begin{array}{l}\text { Primære } \\
\text { variabel- } \\
\text { modsætning } \\
\end{array}$ & $\begin{array}{l}\text { \% forbind. } \\
\text { stat }\end{array}$ & $\begin{array}{l}\text { \% forbind. } \\
\text { erhverv }\end{array}$ & $\begin{array}{l}\text { \% forbind. } \\
\text { forskning }\end{array}$ & $\begin{array}{l}\text { \% forbind. } \\
\text { Fagbev. }\end{array}$ & $\begin{array}{l}\% \text { forbind. } \\
\text { kultur/ me- } \\
\text { dier }\end{array}$ & $\begin{array}{l}\% \text { forbind. } \\
\text { andre org. }\end{array}$ & $\begin{array}{l}\text { Gnms. } \\
\text { degree }\end{array}$ \\
\hline 1 & 3 & $\begin{array}{l}+ \text { Erhverv } \\
\text { - Forskning }\end{array}$ & $0 \%$ & $79 \%$ & $16 \%$ & $3 \%$ & $0 \%$ & $3 \%$ & 13 \\
\hline 2 & 3 & $\begin{array}{l}\text { + Fagbev. } \\
\text { - Kultur/med. }\end{array}$ & $17 \%$ & $28 \%$ & $29 \%$ & $19 \%$ & $1 \%$ & $6 \%$ & 45 \\
\hline 3 & 5 & $\begin{array}{l}\text { + Offentlig } \\
\text { - Andre org. }\end{array}$ & $23 \%$ & $39 \%$ & $28 \%$ & $7 \%$ & $2 \%$ & $1 \%$ & 33 \\
\hline 4 & 3 & $\begin{array}{l}\text { + Forskning } \\
\text { - Kultur/med. }\end{array}$ & $11 \%$ & $24 \%$ & $59 \%$ & $0 \%$ & $1 \%$ & $4 \%$ & 23 \\
\hline 5 & 2 & $\begin{array}{l}\text { + Kultur/med. } \\
\text { - Fagbev. } \\
\text { - Forskning }\end{array}$ & $15 \%$ & $31 \%$ & $23 \%$ & $0 \%$ & $29 \%$ & $3 \%$ & $\begin{array}{l}31 \\
\text { Total } 29\end{array}$ \\
\hline
\end{tabular}

Kilde: (Ellersgaard \& Larsen 2012) samt egne beregninger. 
ydermere 5 klynger, som hver især er karakteriseret ved en særlig høj andel af forbindelser til én samfundsinstitution på bekostning af relativt færre forbindelser til en anden samfundsinstitution. Et næste forskningsmæssigt skridt i retning af en mere fyldestgørende forståelse af vismændenes og andre økonomiske eksperters rolle i policyprocesser kunne være at se på, hvad netværksplacering betyder for deres rent forskningsmæssige indflydelse samt evne til at øve indflydelse på mediebilledet.

\section{Litteratur}

Andersen, TM 2002, 'Det Økonomiske Råds Funktion I dag, Samfundsøkonomen, vol. 8, pp. 4-8.

Backhouse, R 2009, 'Economists and the Rise of Neo-liberalism', Renewal: A Journal of Labour Politics, vol. 17. pp. 17-25

Blyth, M 2002, Great Transformations: Economic Ideas and Institutional Change in the Twentieth Century, New York, Cambridge University Press.

Bonacich, P 1987, 'Power and Centrality: A Family of Measures', American Journal of Sociology vol. 92, pp. 1170-82.

Borgatti, SP 2005, 'Centrality and Network Flow', Social Networks vol. 27, pp. 55-71.

Borgatti, SP \& DS Halgin 2011, 'On Network Theory', Organization Science, vol. 22, pp. 1168-81.

Børsting, H 2012, 'LO’s Syn på Det Økonomiske Råd' in Jubilaumskrift - De Økonomiske Råd 1962-2012, København, Det Økonomiske Råd, pp. 273-279.

Callon, M 1998, Laws of the Market, London, Blackwell Publishers

Callon, M 1986, 'Some Elements of a Sociology of Translation: Domestication of the Scallops and the Fishermen of St Brieuc Bay' in J Law (ed.), Power, Action and

Belief: A New Sociology of Knowledge?, London, Routledge \& Kegan Paul, pp. 196-233.

Callon, M 1983, 'From Translations to Problematic Networks: An Introduction to Co-word Analysis' Social Science Information, vol. 22, 191-235.

Campbell, J. L. (1998). Institutional analysis and the role of ideas in political economy. Theory and Society, 27(3), 377-409.

Carstensen, MB 2011, 'Paradigm Man vs. The Bricoleur: An Alternative Vision of Agency in Ideational Change', European Political Science Review, vol. 3, pp. 147-167.

Christensen, HS 2002, 'Fortsat Behov for Uafhængige Analyser?' Samfundsøkonomen, vol. 8, 36-40.

Chwieroth, JM 2009, Capital Ideas: The IMF and the Rise of Financial Liberalization, Princeton, NJ, Princeton University Press.

Due, J \& JS Madsen 2012, 'Vismændene og Den Danske Model' in Jubilaumskrift - De Økonomiske Råd 1962-2012, København, Det Økonomiske Råd, pp. 317-335.

Ellersgaard, C \& AG Larsen 2012, 'The Danish Elite Network anno 2012', Working Paper, University of Copenhagen, Department of Sociology.

Emirbayer, M 1997, 'Manifesto for a Relational Sociology', American Journal of Sociology, vol. 103, pp. 281-317.

Ferré, L 1995, 'Selection of Components in Principal Component Analysis: A Comparison of Methods', Computation Statistics and Data Analysis, vol. 19, pp. 669-82.
Fine, B 2009, From Economics Imperialism to Freakonomics: The Shifting Boundaries Between Economics and Other Social Sciences, London, Routledge.

Freeman, LC 1979, 'Centrality in Social Networks Conceptual Clarification', Social Networks, vol. 1, pp. 215-239.

Granovetter, M 1985, 'Economic Action and Social Structure. The Problem of Embeddedness', American Journal of Sociology, vol. 91, pp. 481-510.

Hall, PA 1993, 'Policy Paradigms, Social Learning, and the State', Comparative Politics, vol. 25, pp. 275-96.

Hay, C 2001, 'The „Crisis“ of Keynesianism and the Rise of Neoliberalism in Britain: An Ideational Institutionalist Approach' in JL Campbell \& OK Pedersen (eds.), The Rise of Neoliberalism and Institutional Analysis, Oxford, Princeton University Press, pp. 193-218.

Indenrigsministeriet 2007 [1962], Lov om Det Økonomiske Råd og Det Miljøøkonomiske Rad, hentet 4-11-2013 https://www.retsinformation.dk/Forms/R0710.aspx?id=27673

Korpi, W 1996, 'Eurosclerosis and the Sclerosis of Objectivity: On the Role of Values among Economic Policy Experts', The Economic Journal, vol. 106, pp. 1727-1746.

Kristensen, OP 2002, 'Vismændenes Rolle i Forhold til Offentlig Politikformulering, Samfundsøkonomen, vol. 8, pp. 21-25.

Kærgård, N 1996, 'Økonomiske Vismænd - Politiserende Økonomer eller Objektive Eksperter?', Nationaløkonomisk tidsskrift, vol. 134, pp 113-128

Madsen, PT 2009, ‘Økonomiske Sandheder eller bare Sjusket Journalistik? Om Eksperter og Mikrofonholderi’, Økonomi \& Politik, vol 82 , pp. 50-59.

Marcussen, M 2002, 'Det Økonomiske Råd og Kampen om Det Politiske Midtbanespil'. Samfundsøkonomen, vol. 8, pp. 26-36.

Marcussen, M 2000, Ideas and Elites: The Social Construction of Economic and Monetary Union, Aalborg, Aalborg Universitetsforlag.

MacKenzie, D 2006, An Engine, not a Camera, Cambridge, MA, MIT Press.

Mikkelsen, A 1987, 'Plusser og Minusser gennem 25 år: Elementer til Vurdering', in Dansk Økonomi, Råd og Realiteter 1962-1987, København, Det Økonomiske Råd, pp. 185-209

Pedersen, OK 2011, Konkurrencestaten, København, Hans Reitzels Forlag.

Pedersen, OK \& JL Campbell 2014, Knowledge Regimes. The National Origins of Policy Ideas, Princeton, NJ, Princeton University Press.

Schmidt, VA 2011, 'Ideas and Discourse in Transformational Political Economic Change in Europe', in G Skogstad (ed.), Policy Paradigms, Transnationalism and Domestic Politics, Toronto, University of Toronto Press, pp. 36-63.

Scott, J 1991, 'Networks of Corporate Power: A Comparative Assessment', Annual Review of Sociology, vol. 17, 181-203.

Stark, D 2009, The Sense of Dissonance, Princeton, NJ, Princeton University Press.

Sørensen, C 2013, Finanskrisen - Kleptokratiets Konsekvens, København, Tiderne Skifter.

Sørensen, PB \& M Rosholm 2009, Uafhængig Økonomisk-politisk Rådgivning: De Økonomiske Vismænd før og nu, in Udsyn og fremsyn København, DJØFs Forlag, pp. 235-244.

Useem, M 1984, The Inner Circle: Large Corporations and the Rise of Business Political Activity in the US and UK, Oxford, Oxford University Press.

Vestergaard, F 2002, Vismændene og medierne. Samfundsøkono$\operatorname{men}(8), 45-48$.

Wellman, B 1997, 'Structural Analysis: From Method and Metaphor to Theory and Substance', in B Wellman \& SD Berkowitz (eds.), 
Social Structures: A Network Approach, Cambridge, Cambridge University Press.

Whitta-Jacobsen, HJ 2012, 'Økonomisk Råd i 50 år', in Jubilaumskrift - De Økonomiske Råd 1962-2012, København, Det Økonomiske Råd, pp. 7-11.

Ølgaard, A 2002, 'Vismændene og Den Offentlige Debat' Samfundsokonomen, vol. 8, pp. 8-15.

Ølgaard, A 1977, 'Om Politiserende Økonomer - med Særligt Henblik på Den Danske „vismands“institution', Nationalokonomisk Tidsskrift, vol. 115, pp. 122-156.

\section{Noter}

1. Dele af forskningen til denne artikel er støttet af projektet „Professions in International Political Economies, “European Research Council, Grant Agreement \#263741-PIPES.

2. Før 2007 med oprettelsen af det miljøøkonomiske råd, bestod formandskabet af 3 økonomer. http://dors.dk/sw2876.asp

3. Studiet undersøger Danmark, Frankrig, USA og Tyskland.

4. I de senere år har Callon ikke gjort anvendelse af kvantitative netværksmetoder, selvom han tidligere i sin karriere har begået væsentlige bidrag inden for scientometrien (se bl.a. Callon 1983), hvor netværksanalysen fortrinsvis har været anvendt til at kortlægge organiseringen af videnskabeligt samarbejde.

5. Disse organisationer inkluderer de 1000 største virksomheder, NGO'er med officiel høringsret, 152 statslige råd og nævn, samt 1300 private fonde.

6. De manglende personer skyldes, at personerne enten er afdøde eller ikke havde poster i datasættet.

7. I de analyser, hvor vismændene ikke er trukket frem som selvstændig gruppe, er vismændene kategoriseret som tilhørende forskning.

8. Kontrolgruppen udgøres af samtlige økonomiprofessorer fra København Universitet, Århus Universitet, Aalborg Universitet, Syddansk Universitet, Roskilde Universitet og Copenhagen Business School.

9. De væsentlige centralitetsbegreber er Eigenvektor-, reach-(eller closeness) og betweeness-centralitet. Eigenvektor-centralitet er sensitiv over for aktørers forbundethed i andet led, dvs. forbindelsernes forbundethed. Reach-centralitet betegner den gennemsnitlige distance (målt som stier) til andre aktører i et netværk og anvendes derfor ofte som et mål for rækkevidde. Et yderligere mål, som ofte anvendes, når en aktørs centralitet i det samlede netværk skal måles, er betweenness-centralitet, som måler, hvor mange andre der skal gennem den pågældende for at nå endnu andre i netværket (Freeman 1979:221). 